\title{
Supramolecular architectures in crystals of melamine and aromatic carboxylic acids
}

\author{
Genivaldo Julio Perpétuo ${ }^{\mathrm{a}}$, Jan Janczak ${ }^{\mathrm{b}, *}$ \\ ${ }^{a}$ Departamento de Física, Instituto de Ciências Exatas e Biológicas, Universidade Federal de Ouro Preto, 35400-000 Ouro Preto, MG, Brazil \\ ${ }^{\mathrm{b}}$ Institute of Low Temperature and Structure Research, Polish Academy of Sciences, PO Box 1410, 50950 Wroclaw, Poland
}

\section{A R T I C L E I N F O}

\section{Article history:}

Received 24 January 2008

Received in revised form 9 April 2008

Accepted 12 April 2008

Available online 25 April 2008

\section{Keywords:}

Co-crystals

Melamine

Supramolecular architecture

Hydrogen bond

Carboxylic acid

Crystal engineering

\begin{abstract}
A B S T R A C T
Two crystals containing melamine (M), melaminium $\left(\mathrm{MH}^{+}\right)$, and aromatic carboxylic acids are synthesized and characterized by single-crystal X-ray diffraction analysis: melamine-melaminium 3,4,5-trihydroxybenzoate $\left(\mathrm{THB}^{-}\right)$dihydrate $(\mathbf{1})$, and melamine-melaminium 2-acetylbenzoate $\left(\mathrm{AB}^{-}\right)$dihydrate $(\mathbf{2})$. In the crystal structures protonated $\left(\mathrm{MH}^{+}\right)$and non-protonated melamine $(\mathrm{M})$ molecules are interconnected via $\mathrm{N}-\mathrm{H} \cdots \mathrm{N}$ hydrogen bonds into a planar dimer in (1) and one-dimensional polymer in (2). The $\mathrm{N}-\mathrm{H} \cdots \mathrm{O}$ hydrogen bonding interaction between the protonated nitrogen atom of $\mathrm{MH}^{+}$and the carboxylate oxygen atom of the corresponding anion is observed in both structures. However, only in (1) it results in an almost planar ionic unit $\left(\mathrm{THB}^{-} \mathrm{MH}^{+}\right)$where additional $\pi-\pi$ interactions between the anions appear, that are missing in (2). The water molecules act as donor and as acceptor of hydrogen bonds linking the substructures observed in the (1) and (2) crystals into 3D supramolecular networks.
\end{abstract}

() 2008 Elsevier B.V. All rights reserved.

\section{Introduction}

A productive strategy in the crystal engineering is to build supramolecular structures from molecules that are programmed to engage in multiple interactions with the neighbours [1-3]. Hydrogen bonding system is the main key for organisation of molecules containing complementary arrays of the hydrogen bonding sites [4-8]. The $\mathrm{N}-\mathrm{H} \cdots \mathrm{N}, \mathrm{N}-\mathrm{H} \cdots \mathrm{O}$, and $\mathrm{O}-\mathrm{H} \cdots \mathrm{O}$ hydrogen bonds are widely used for organisation of the components in the design of a large number and different types of supramolecular architectures as ribbons, rosettes, layers, tubes, rods, spheres and sheets [9-14]. Some supramolecular motifs of hydrogen bonding patterns of symmetric and translational repetitive occurrence are important in the crystal and chemical engineering and technology [15]. The usually weak $\mathrm{C}-\mathrm{H} \cdots \mathrm{N}$ and $\mathrm{C}-\mathrm{H} \cdots \mathrm{O}$ hydrogen bonds play also a significant role in the architectures, especially in the biological systems [16-18]. A non-covalent association of proteins, formation of a phospholipid bilayer, interaction of a transcription factor with DNA, folding of a tRNA into its three-dimensional conformation are examples of processes that depend on the non-covalent interactions and organisations [18].

Melamine is an example of a compound containing complementary arrays of hydrogen bonding sites that forms in the solid state a two dimensional network (Scheme 1a). Protonation of its triazine ring decreases the number of the active sites resulting in decreasing of the dimensionality of the arrangement; for example

\footnotetext{
* Corresponding author. Fax: +48 713441029.

E-mail address: j.janczak@int.pan.wroc.pl (J. Janczak).
}

singly protonated melaminium cations form one-dimensional hydrogen bonded chains (Scheme $1 \mathrm{~b}$ ), while double protonated melaminium cations form only a dimeric structure (Scheme 1c). Our interest in melamine and its complexes or salts arises from the possibility to obtain a new material for non-linear optics. Crystals of melaminium selenate with non-centrosymmetric space group are optically active and generate the SHG (second harmonic generation) with c.a. $40 \%$ efficiency of $\mathrm{KDP}\left(\mathrm{KDP}=\mathrm{KH}_{2} \mathrm{PO}_{4}\right)$ [19]. High efficiency of SHG is observed in the crystals of double protonated melaminium bis(trichloroacetate) dihydrate (about 3-times greater than that of KDP) [20]. Another non centrosymmetric crystal of melaminium phosphate may also be used as a material for non-linear optics [21]. One of the most interesting hydrogen bonded structure formed by melamine is with cyanuric and thiocyanuric acids [22]. In both co-crystals of the 1:1 hydrogen bonded adducts of melamine $(\mathrm{M})$ and cyanuric acid (CA) or thiocyanuric acid (TCA) form pseudohexagonal rosette arrangement with channels along the shortest crystallographic axis [22].

Compounds containing partially protonated melaminium cations $\left(\mathrm{MH}^{+}, \mathrm{MH}_{2}{ }^{2+}\right)$ combined with different organic and inorganic counterions are widely reported in the literature [23-24]. In studies of the crystalline melamine and its organic or inorganic salts, the most crystals contain only one melamine form, i.e. the neutral molecule, singly or doubly protonated melaminium cations [25], and only two works reporting the crystalline structure of neutral and protonated melminie $\left(\mathrm{M}\right.$ and $\left.\mathrm{MH}^{+}\right)[26,27]$. In the present work we describe two co-crystals containing protonated $\left(\mathrm{MH}^{+}\right)$ and non-protonated melamine: melamine-melaminium 3,4,5-trihydroxybenzoate dihydrate (1) and melamine-melaninium 


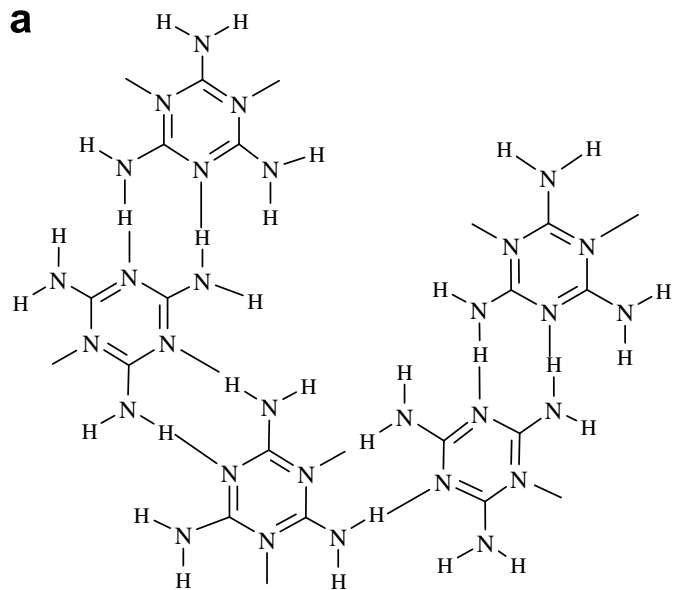

b

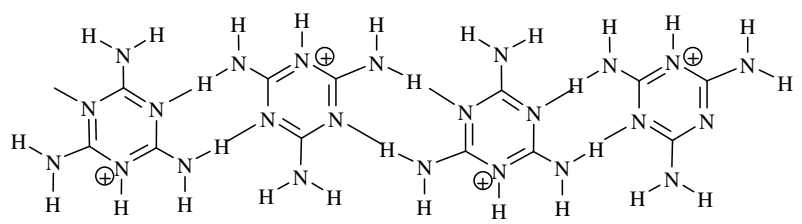

C

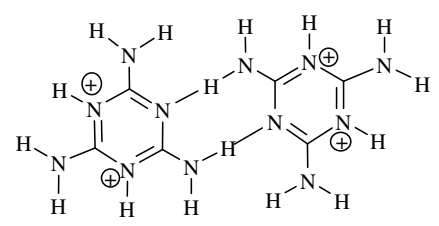

Scheme 1. Possible dimensionality of melamine arrangements by increasing degree of protonation: 2D-layer of non-protonated (a), polymeric 1D-chain (b), and discrete dimeric form (c).

2-acetylbenzoate dihydrate (2). Both crystals investigated here are the examples containing neutral melamine $\mathrm{M}$ and singly protonated melaminium $\mathrm{MH}^{+}$cation in the same crystal.

Another feature observed in several structures containing the melaminium cation concerns its tendance to dimerization; generally pairs of $\mathrm{MH}^{+}$units are linked via two almost linear $\mathrm{N}_{\text {amine }}$ $-\mathrm{H} \cdots \mathrm{N}_{\mathrm{aza}}$ hydrogen bonds to form a planar dimer [25]. The question if these dimers will provide formation of especially long ordered arrangement in the crystals like $1 \mathrm{D}$ polymeric chains or tapes, or even 2D layers, depends not only on the surrounding counterions and water molecules, but also on the site of the protonation within the triazine ring relative to the dimer as a building unit. In the present study we attempt to answer the crucial questions concerning the competitive forces toward the stabilization of the crystal structures, such as the $\pi-\pi$ interactions, the attractive and repulsive Coulomb forces and the participation of aza and amine nitrogen sites. The role of water molecules in formation of short and long ordered molecular arrangements is also discussed. For completeness, in each case the building units in the asymmetric unit of $\mathbf{1}$ and $\mathbf{2}$ are optimized and theirs geometries are analysed in relation to those in the crystal.

\section{Experimental}

All materials were commercially available and used as received. The Fourier transform infrared spectra were recorded from nujol mulls between 400 and $4000 \mathrm{~cm}^{-1}$ on a Bruker IFS 113 V FTIR spec- trometer at room temperature. Elemental analyses were carried out with a Perkin-Elmer 240 elemental analyzer. Thermogravimetric analyses (TGA) were performed under dinitrogen atmosphere using a Perkin-Elmer 7 thermogravimetric analyzer with a heating rate of $5{ }^{\circ} \mathrm{C}$ min. The co-crystals were prepared as follows.

\subsection{Preparation of (1)}

Melamine and 3,4,5-trihydroxybenzoic acid (Aldrich, purity: $99 \%$ and $98 \%$ ) were solved in hot water in 1:1 molar ratio. The hot solution was cooled slowly and kept at room temperature. After several days transparent yellowish crystals were formed. Anal. calculated for $\mathrm{C}_{13} \mathrm{H}_{22} \mathrm{~N}_{12} \mathrm{O}_{7}$ : C, 34.06; $\mathrm{H}, 4.84 ; \mathrm{N}, 36.67 ; \mathrm{O}$, 24.43\%. Found: C, 34.28; H, 4.76; N, 36.43. IR $\left(\mathrm{cm}^{-1}\right)$ : 3468, 3418, 3329, 3128, 1653, 1551, 1377, 1210, 1027, 813.

\subsection{Preparation of (2)}

Melamine and 2-acetylbenzoic acid (Aldrich, both purity of 99\%) were solved in hot water in 1:1 molar ratio. The hot solution was cooled slowly and kept at room temperature. After several days transparent yellowish crystals were formed. Anal. calculated for $\mathrm{C}_{15} \mathrm{H}_{24} \mathrm{~N}_{12} \mathrm{O}_{5}$ : C, 40.02; H, 5.01; N, 36.98; O, 17.98\%. Found: C, 40.12; H, 4.93; N, 36.81. IR $\left(\mathrm{cm}^{-1}\right): 3466,3415,3327,3129,1695$, 1613, 1580, 1493, 1450, 1372, 1203, 1030, 814.

\subsection{X-ray single crystal analysis}

X-ray intensity data for both crystals were collected using graphite monochromatic MoK $\alpha$ radiation on a four-circle $\kappa$-geometry KUMA KM-4 diffractometer with a two-dimensional area

Table 1

Crystallographic data and structure refinement parameters

\begin{tabular}{|c|c|c|}
\hline Crystal data & 1 & 2 \\
\hline Formula & $\mathrm{C}_{7} \mathrm{H}_{5} \mathrm{O}_{5} \cdot \mathrm{C}_{3} \mathrm{H}_{7} \mathrm{~N}_{6} \cdot \mathrm{C}_{3} \mathrm{H}_{6} \mathrm{~N}_{6} \cdot 2\left(\mathrm{H}_{2} \mathrm{O}\right)$ & $\mathrm{C}_{9} \mathrm{H}_{7} \mathrm{O}_{3} \cdot \mathrm{C}_{3} \mathrm{H}_{7} \mathrm{~N}_{6} \cdot \mathrm{C}_{3} \mathrm{H}_{6} \mathrm{~N}_{6} \cdot 2\left(\mathrm{H}_{2} \mathrm{O}\right)$ \\
\hline $\mathrm{MW}\left(\mathrm{g} \mathrm{mol}^{-1}\right)$ & 458.43 & 452.46 \\
\hline Crystal size & $0.45 \times 0.24 \times 0.18 \mathrm{~mm}$ & $0.35 \times 0.28 \times 0.24 \mathrm{~mm}$ \\
\hline Crystal system & Orthorhombic & Monoclinic \\
\hline Space group & Pcnn & $\mathrm{C} 2 / \mathrm{c}$ \\
\hline$a(\AA)$ & $32.878(5)$ & $12.286(3)$ \\
\hline$b(\AA)$ & $9.392(2)$ & $18.934(4)$ \\
\hline$c(\AA)$ & $12.785(2)$ & $18.515(4)$ \\
\hline$\beta\left(^{\circ}\right)$ & & $95.26(3)$ \\
\hline$V\left(\AA^{3}\right)$ & 3947.9(12) & $4288.9(17)$ \\
\hline$Z$ & 8 & 8 \\
\hline$\mu\left(\mathrm{mm}^{-1}\right)$ & 0.127 & 0.109 \\
\hline $\begin{array}{l}\rho_{\text {obs }} ; \rho_{\text {calc }} \\
\quad\left(\mathrm{g} \mathrm{cm}^{-3}\right)\end{array}$ & $1.54 ; 1.543$ & $1.40 ; 1.401$ \\
\hline \multicolumn{3}{|l|}{ Data collection } \\
\hline Radiation, $\lambda(\AA)$ & Mo K $\alpha(0.71073)$ & Mo K $\alpha(0.71073)$ \\
\hline$\theta_{\max }\left({ }^{\circ}\right)$ & 28.49 & 28.40 \\
\hline $\begin{array}{l}\text { Absorpt. } \\
\text { correct. } \\
\left(T_{\min } ; T_{\max }\right)\end{array}$ & $0.9451 ; 0.9775$ & $0.9603 ; 0.9715$ \\
\hline$R_{\text {int }}$ & 0.0222 & 0.0176 \\
\hline $\begin{array}{l}\text { No. collected } \\
\text { reflections }\end{array}$ & 45212 & 24078 \\
\hline $\begin{array}{l}\text { No. unique } \\
\text { reflections }\end{array}$ & 4992 & 5350 \\
\hline $\begin{array}{l}\text { No. observed } \\
\text { reflections }\end{array}$ & 3997 & 3571 \\
\hline \multicolumn{3}{|l|}{ Refinement } \\
\hline$R\left[F^{2}>2 \sigma\left(F^{2}\right)\right]$ & 0.0456 & 0.0518 \\
\hline $\mathrm{w} R\left(F^{2}\right)^{\mathrm{a}, \mathrm{b}}$ & 0.1086 & 0.1489 \\
\hline GooF & 1.005 & 1.006 \\
\hline $\begin{array}{l}\Delta \rho_{\min } ; \Delta \rho_{\max } \\
\quad\left(\mathrm{e} \AA^{-3}\right)\end{array}$ & $-0.426 ; 0.642$ & $-0.211 ; 0.231$ \\
\hline
\end{tabular}

a $w=1 /\left[\sigma^{2}\left(F_{\mathrm{o}}{ }^{2}\right)+(0.0466 P)^{2}+1.600 P\right]$ where $P=\left(F_{\mathrm{o}}{ }^{2}+2 F_{\mathrm{c}}{ }^{2}\right) / 3$.

b $w=1 /\left[\sigma^{2}\left(F_{\mathrm{o}}{ }^{2}\right)+(0.0920 P)^{2}+0.8200 P\right]$ where $P=\left(F_{\mathrm{o}}{ }^{2}+2 F_{\mathrm{c}}{ }^{2}\right) / 3$. 
CCD detector. The $\omega$-scan technique with $\Delta \omega=0.75^{\circ}$ for each image was used for data collection. The 960 images for six different runs covering over 95\% of the Ewald sphere were performed. Initially the lattice parameters were refined on 150 reflections obtained from 40 images for eight runs with different orientation in the reciprocal space. Finally the lattice parameters were refined by least-squares methods based on all the reflections with $I>2 \sigma\left(F^{2}\right)$. One image was used as a standard after every 40 images for monitoring of the crystal's stability as well as for monitoring the data collection, and no correction on the relative intensity variation was necessary. Integration of the intensities, correction for Lorenz and polarization effects was performed using a KUMA KM-4 CCD program [28]. The face-indexed analytical absorption was calculated using the SHELXTL program [29]. The structures were solved by direct methods using SHELXS of the SHELXL97 program [30]. The structures were refined with the anisotropic thermal parameters for all non-hydrogen atoms. Difference Fourier maps gave electron density concentrations approximately located for all hydrogen atoms positions; these positions were idealised (HFIX 43 for all $\mathrm{H}$ atoms of the phenyl rings with isotropic thermal parameters of $1.2 \mathrm{U}_{\mathrm{eq}}$ of the carbon atoms joined directly to the hydrogen atoms). Final difference Fourier maps showed no peaks of chemically significance. Details of the data collection parameters and final agreement factors are collected in Table 1 . Selected bond lengths and angles and torsion angles are listed in Table 2.

\subsection{Quantum calculations}

Ab-initio molecular orbital calculations full geometry optimisation were performed with the Gaussian98 program package [31]. a

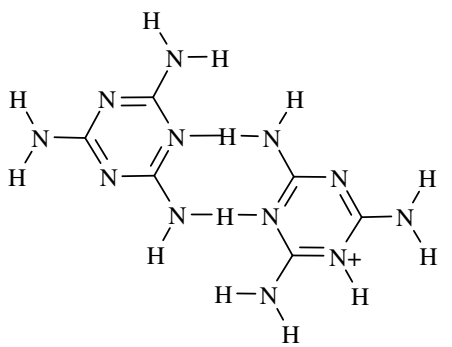

b<smiles></smiles>

C<smiles></smiles>

Scheme 2. Hydrogen bonding motifs in the crystal structures of $\mathbf{1}$ ( $\mathrm{a}$ and $\mathrm{b}$ ) and $\mathbf{2}$ (a and c).

Table 2

Selected geometric parameters (bond lengths in $\AA$, bond angles in degrees)

\begin{tabular}{|c|c|c|c|c|c|c|c|c|}
\hline \multirow[t]{2}{*}{$(\mathrm{MH})^{+}$} & \multicolumn{2}{|l|}{ X-ray } & & \multirow{2}{*}{\multicolumn{2}{|c|}{ Melamine }} & \multicolumn{2}{|l|}{ X-ray } & \multirow[t]{2}{*}{ Theoretical } \\
\hline & 1 & \multicolumn{2}{|l|}{2} & & & \multicolumn{2}{|l|}{1} & \\
\hline $\mathrm{N} 11-\mathrm{C} 12$ & $1.344(2)$ & \multicolumn{2}{|l|}{$1.348(2)$} & \multicolumn{2}{|l|}{$\mathrm{N} 21-\mathrm{C} 22$} & $1.349(2)$ & $1.344(2)$ & 1.325 \\
\hline $\mathrm{N} 11-\mathrm{C} 16$ & $1.332(2)$ & \multicolumn{2}{|l|}{$1.326(2)$} & \multicolumn{2}{|l|}{$\mathrm{N} 21-\mathrm{C} 26$} & $1.351(2)$ & $1.345(2)$ & 1.326 \\
\hline $\mathrm{N} 13-\mathrm{C} 12$ & $1.352(2)$ & \multicolumn{2}{|l|}{$1.353(2)$} & \multicolumn{2}{|l|}{$\mathrm{N} 23-\mathrm{C} 22$} & $1.339(2)$ & $1.348(2)$ & 1.325 \\
\hline $\mathrm{N} 13-\mathrm{C} 14$ & $1.331(2)$ & \multicolumn{2}{|l|}{$1.332(2)$} & \multicolumn{2}{|l|}{$\mathrm{N} 23-\mathrm{C} 24$} & $1.345(2)$ & $1.344(2)$ & 1.326 \\
\hline $\mathrm{N} 15-\mathrm{C} 14$ & $1.362(2)$ & \multicolumn{2}{|l|}{$1.359(2)$} & \multicolumn{2}{|l|}{$\mathrm{N} 25-\mathrm{C} 24$} & $1.346(2)$ & $1.343(2)$ & 1.325 \\
\hline $\mathrm{N} 15-\mathrm{C} 16$ & $1.358(2)$ & \multicolumn{2}{|l|}{$1.361(2)$} & \multicolumn{2}{|l|}{$\mathrm{N} 25-\mathrm{C} 26$} & $1.335(2)$ & $1.348(2)$ & 1.326 \\
\hline $\mathrm{C} 12-\mathrm{N} 17$ & $1.337(2)$ & \multicolumn{2}{|l|}{$1.328(2)$} & \multicolumn{2}{|l|}{$\mathrm{C} 22-\mathrm{N} 27$} & $1.340(2)$ & $1.337(2)$ & 1.344 \\
\hline $\mathrm{C} 14-\mathrm{N} 18$ & $1.324(2)$ & \multicolumn{2}{|l|}{$1.320(2)$} & \multicolumn{2}{|l|}{$\mathrm{C} 24-\mathrm{N} 28$} & $1.333(2)$ & $1.348(2)$ & 1.344 \\
\hline C16-N19 & $1.319(2)$ & \multicolumn{2}{|l|}{$1.324(2)$} & \multicolumn{2}{|l|}{$\mathrm{C} 26-\mathrm{N} 29$} & $1.337(2)$ & $1.333(2)$ & 1.344 \\
\hline C12-N11-C16 & $115.4(2)$ & \multicolumn{2}{|l|}{$115.8(2)$} & \multicolumn{2}{|l|}{$\mathrm{C} 22-\mathrm{N} 21-\mathrm{C} 26$} & $114.2(2)$ & $114.8(2)$ & 114.03 \\
\hline N11-C12-N13 & $126.7(2)$ & $126.0(2)$ & & $\mathrm{N} 21-\mathrm{C} 22-\mathrm{N} 23$ & & $125.2(2)$ & $125.3(2)$ & 125.97 \\
\hline C12-N13-C14 & $114.8(2)$ & $115.9(2)$ & & $\mathrm{C} 22-\mathrm{N} 23-\mathrm{C} 24$ & & $115.3(2)$ & $114.3(2)$ & 114.03 \\
\hline N13-C14-N15 & $122.1(2)$ & $121.1(2)$ & & $\mathrm{N} 23-\mathrm{C} 24-\mathrm{N} 25$ & & $124.5(2)$ & $125.9(2)$ & 125.97 \\
\hline C14-N15-C16 & $118.9(2)$ & $119.8(2)$ & & $\mathrm{C} 24-\mathrm{N} 25-\mathrm{C} 26$ & & $115.2(2)$ & $114.3(2)$ & 114.03 \\
\hline N11-C16-N15 & $121.8(2)$ & $121.5(2)$ & & $\mathrm{N} 21-\mathrm{C} 26-\mathrm{N} 21$ & & $125.6(2)$ & $125.3(2)$ & 125.97 \\
\hline$(\mathrm{THB})^{-}(\mathbf{1})$ & X-ray & & Theoretical & & $(A B)^{-}(2)$ & & X-ray & Theoretical \\
\hline $\mathrm{C} 1-\mathrm{C} 2$ & $1.397(2)$ & & 1.402 & & $\mathrm{C} 1-\mathrm{C} 2$ & & $1.405(2)$ & 1.405 \\
\hline $\mathrm{C} 2-\mathrm{C} 3$ & $1.386(2)$ & & 1.390 & & $\mathrm{C} 2-\mathrm{C} 3$ & & $1.399(2)$ & 1.403 \\
\hline $\mathrm{C} 3-\mathrm{C} 4$ & $1.391(2)$ & & 1.394 & & $\mathrm{C} 3-\mathrm{C} 4$ & & $1.389(2)$ & 1.398 \\
\hline $\mathrm{C} 4-\mathrm{C} 5$ & $1.387(2)$ & & 1.397 & & $\mathrm{C} 4-\mathrm{C} 5$ & & $1.373(2)$ & 1.400 \\
\hline $\mathrm{C} 5-\mathrm{C} 6$ & $1.388(2)$ & & 1.394 & & C5-C6 & & $1.388(2)$ & 1.397 \\
\hline $\mathrm{C} 6-\mathrm{C} 1$ & $1.389(2)$ & & 1.401 & & $\mathrm{C} 6-\mathrm{C} 1$ & & $1.388(2)$ & 1.400 \\
\hline $\mathrm{C} 1-\mathrm{C} 7$ & $1.504(2)$ & & 1.554 & & $\mathrm{C} 1-\mathrm{C} 7$ & & $1.510(2)$ & 1.538 \\
\hline $\mathrm{C} 7-\mathrm{O} 1$ & $1.257(2)$ & & 1.258 & & $\mathrm{C} 7-\mathrm{O} 1$ & & $1.255(2)$ & 1.266 \\
\hline $\mathrm{C} 7-\mathrm{O} 2$ & $1.273(2)$ & & 1.261 & & $\mathrm{C} 7-\mathrm{O} 2$ & & $1.248(2)$ & 1.254 \\
\hline $\mathrm{C} 3-\mathrm{O} 3$ & $1.370(2)$ & & 1.397 & & $\mathrm{C} 2-\mathrm{C} 8$ & & $1.487(2)$ & 1.513 \\
\hline $\mathrm{C} 4-\mathrm{O} 4$ & $1.362(2)$ & & 1.391 & & C8-C9 & & $1.499(2)$ & 1.522 \\
\hline $\mathrm{C} 5-\mathrm{O} 5$ & $1.377(2)$ & & 1.392 & & $\mathrm{C} 8-\mathrm{O} 3$ & & $1.224(2)$ & 1.228 \\
\hline $\mathrm{C} 1-\mathrm{C} 7-\mathrm{O} 1$ & $119.75(12)$ & & 115.6 & & $\mathrm{C} 1-\mathrm{C} 7-\mathrm{O} 1$ & & $116.01(13)$ & 113.6 \\
\hline $\mathrm{C} 1-\mathrm{C} 7-\mathrm{O} 2$ & 117.57(13) & & 115.1 & & $\mathrm{C} 1-\mathrm{C} 7-\mathrm{O} 2$ & & 118.79(13) & 117.2 \\
\hline $\mathrm{O} 1-\mathrm{C} 7-\mathrm{O} 2$ & $122.67(13)$ & & 129.3 & & $\mathrm{O} 1-\mathrm{C} 7-\mathrm{O} 2$ & & $125.11(14)$ & 129.2 \\
\hline & & & & & $\mathrm{C} 2-\mathrm{C} 8-\mathrm{C} 9$ & & $119.46(15)$ & 118.0 \\
\hline & & & & & $\mathrm{C} 2-\mathrm{C} 8-\mathrm{O} 3$ & & $120.94(14)$ & 120.0 \\
\hline & & & & & $\mathrm{C} 9-\mathrm{C} 8-\mathrm{O} 3$ & & 119.61(16) & 120.3 \\
\hline
\end{tabular}


All calculations were performed by the density functional threeparameters hybrid (B3LYP) methods $[32,33]$ with the $6-31 \mathrm{G}(\mathrm{d}, \mathrm{p})$ basis set starting from the X-ray geometry. As convergence criterions the threshold limits of 0.00025 and 0.0012 a.u. were applied for the maximum force and the displacement, respectively.

\section{Results and discussion}

The crystallizations of melamine in hot water solution of 3,4,5trihydroxybenzoic acid as well as in 2-acetylbenzoic acid were carried out in a 1:1 molar ratio, but the formed crystals contained 2:1 ratios of melamine to carboxylic acid. The crystallizations were also performed in a molar proportion of $2: 1$, but the formed crystals were not suitable for the X-ray analysis. In both co-crystals, the carboxylic proton is transferred to the melamine molecule leading to singly protonated $\left(\mathrm{MH}^{+}\right)$unit, which interacts with non-protonated melamine $(\mathrm{M})$ to form a dimeric unit $\left(\mathrm{MH}^{+} \mathrm{M}\right)$ (Scheme 2a); the latter interacts with anionic part of the crystals by a pair of $\mathrm{N}-\mathrm{H} \cdots \mathrm{O}$ hydrogen bonds with a graph set of $\mathrm{R}_{2}{ }^{2}(8)$ in 1 or of $R_{2}^{2}(11)$ in 2 as illustrated in Scheme $2 b$ and $c$. The first graph $\left(\mathrm{R}_{2}{ }^{2}(8)\right)$ is one of the 24 most frequently observed bimolecular cyclic hydrogen-bonded synthons in organic crystal structures [34,35].

The asymmetric unit of 1 consists of a melamine molecule (M), a protonated melaminium $\left(\mathrm{MH}^{+}\right)$cation, a 3,4,5-trihydroxybenzoate ( $\mathrm{THB}^{-}$) anion, and two water molecules (06 and 07), (Fig. 1a), and the asymmetric unit of 2 consists of the melamine molecule, a protonated melaminium cation, 2-acetyl-benzoate $\left(\mathrm{AB}^{-}\right)$anion, and two water molecules (04 and O5), (Fig. 1b). A search in the Cambridge Structural Data Base for structures containing melaminium residues yield 26 structures of single-protonated, four structures of double-protonated melamine residues and only three structure containing neutral melamine and singly protonated melamine [25-27]. Thus the structures described here are rare examples of both neutral $(\mathrm{M})$ and protonated $\left(\mathrm{MH}^{+}\right)$units co-existing in the same environment. In nearly all cases, as in the present work, the triazine rings of $\mathrm{M}^{+}$and $\mathrm{M}$ are almost planar, but the bond lengths and especially the internal angles within the rings deviate significantly from the ideal hexagonal form. A correlation between the $\mathrm{N}_{\text {ring }}-\mathrm{C}$ bond lengths and their position in relation to the protonated nitrogen atom in the ring is observed (see Table 2). For example, generally the non-protonated $\mathrm{N}-\mathrm{C}$ bond values are within the expected range for $\mathrm{C}_{\mathrm{ar}}-\mathrm{N}, 1.328(2)$ to $1.348(2) \AA$ [36], while the protonated $\mathrm{N}_{\text {ring }}-\mathrm{C}$ bonds are slightly above of this range. The internal $\mathrm{C}-\mathrm{N}-\mathrm{C}$ bond angles at the protonated nitrogen atom is about four degrees larger than at the non-protonated nitrogen atoms. The differences between the internal $\mathrm{C}-\mathrm{N}-\mathrm{C}$ angles within the protonated melaminium ring are in agreement with the valence-shell electron-pair repulsion model, VSEPR [37], according to which the lone pair on non-protonated aza nitrogen atoms afford a wider region than the covalent bond $\mathrm{N}_{\text {prot }}-\mathrm{H}$, causing the internal angle of the last to be greater than on the nonprotonated
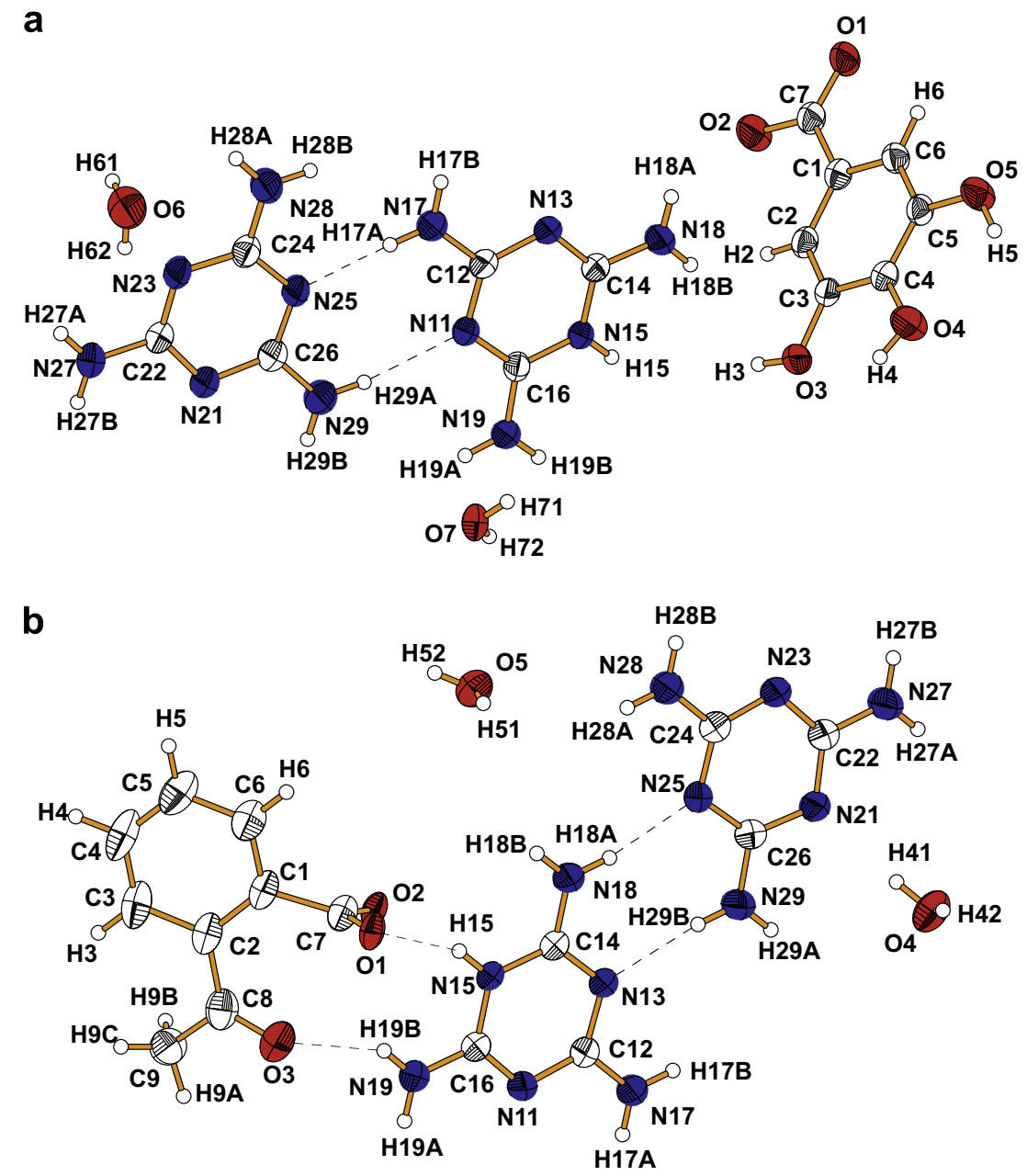

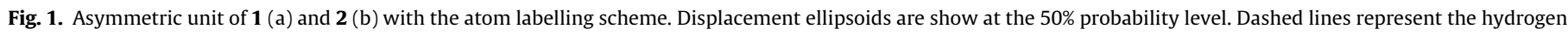
bonds. 
$\mathrm{N}_{\text {ring }}$ atoms. As a result of the protonation of the melamine ring at one of three $\mathrm{N}$ atoms, the internal $\mathrm{N}-\mathrm{C}-\mathrm{N}$ angle involving nonprotonated $\mathrm{N}$ atoms is significantly greater than the remaining two $\mathrm{N}-\mathrm{C}-\mathrm{N}$ angles involving protonated and non-protonated $\mathrm{N}$ atoms. The ab-initio gas-phase geometry calculated for isolated melamine molecule and it's singly protonated cation shows similar correlation between the internal $\mathrm{C}-\mathrm{N}-\mathrm{C}$ and $\mathrm{C}-\mathrm{N}-\mathrm{C}$ angles within the rings as found in these crystals (Table 2). Thus the ring distortions of $\mathrm{MH}^{+}$in comparison to $\mathrm{M}$ result mainly from the protonation, and to a lesser degree, from the hydrogen-bonding system and crystal packing forces.

The whole $\mathrm{THB}^{-}$anion in the crystal of 1 is almost planar. The greatest deviations from the mean plane defined by the benzene ring are $0.061(2) \AA$ for C7 and 0.194(2) $\AA$ for O2 atoms. All of the C...C bond distances within the ring are in the range from $1.375(2)$ to $1.391(2) \AA$, and the internal angles are slightly different from $120^{\circ}$, and they agree well with the average geometry parameters observed in aromatic organic compounds [34]. Furthermore, the hydroxyl groups are bonded to $C_{a r}$ atoms through the typical single-bond value with the average of $1.370 \AA$. A weak intramolecular $\mathrm{O} 4-\mathrm{H} 4 \cdots \mathrm{O} 3$ hydrogen bond is observed $(\mathrm{O} 4-\mathrm{H} 4 \cdots \mathrm{O} 3$, with a 04...03 distance of 2.701(2) $\AA$ ). The values of the two C...O bond lengths of carboxylate group are intermediate between the single $\mathrm{C}_{\mathrm{sp}}{ }^{2}-\mathrm{O}(1.308-1.320 \AA)$ and double $\mathrm{C}_{\mathrm{sp}}{ }^{2}=0$ bonds $(1.214-$ $1.224 \AA$ ) [36] indicating delocalization of the charge on both oxygen atoms of the $\mathrm{COO}^{-}$group. However, the small difference between the two $\mathrm{C}-\mathrm{O}$ distances results from the hydrogen bonds, in which the $\mathrm{O}$ atoms act as acceptors $\mathrm{H}$. The oxygen of the longer $\mathrm{C}-\mathrm{O}$ bond is involved in two stronger hydrogen bonds, while the second oxygen is also involved in two hydrogen bonds, but they are weaker (see Table 3). Comparison of the X-ray experimental and gas-phase molecular orbital geometries of the $\mathrm{TBA}^{-}$anion shows that the greatest differences are observed in the $\mathrm{O}-\mathrm{C}-\mathrm{O}$ angle of the $\mathrm{COO}^{-}$group and in the $\mathrm{C}_{\mathrm{ar}}-\mathrm{COO}^{-}$bond length (Table 2 ). The shortening of the $\mathrm{Car}_{\mathrm{ar}}-\mathrm{COO}^{-}$bond and decreasing of the $\mathrm{O}-\mathrm{C}-\mathrm{O}$ angle in the crystal geometry in relation to $\mathrm{MO}$ geometry is probably due to the interactions with the neighbourhood by almost linear $\mathrm{N}-\mathrm{H} \cdots \mathrm{O}$ and $\mathrm{O}-\mathrm{H} \cdots \mathrm{O}$ hydrogen bonds that diminish the steric effect of the lone-pairs of electron on both $\mathrm{O}$ atoms of the $\mathrm{COO}^{-}$group in the crystals.

The benzene ring (mean plane $\mathrm{P} 1$ : $\mathrm{C} 1-\mathrm{C} 6$ ) of the $\mathrm{AB}^{-}$anion in the crystal of 2 is planar. The acetyl C8 and carboxyl C7 atoms are bonded to the benzene ring on $\mathrm{C} 2$ and $\mathrm{C} 1$, respectively, with the $\mathrm{C}_{\mathrm{ar}}-\mathrm{C} 8$ and $\mathrm{C}_{\mathrm{ar}}-\mathrm{C} 7$ bond lengths of $1.487(2)$ and $1.510(2) \AA$, typical values for $C_{a r}-C$ single bonds [36]. Due to the repulsive interaction between acetyl and carboxyl groups, C8 and C7 atoms deviate from the mean plane of benzene ring by $0.101(2)$ and 0.050 (2) Å respectively, while the $\mathrm{C} 1-\mathrm{C} 2$ bond $(1.405(2) \AA)$ is longer than the remaining $\mathrm{C}-\mathrm{C}$ bonds within the ring (average value of $1.387 \AA$ ). The charge of deprotonated carboxyl group is delocalized over both $\mathrm{C}-\mathrm{O}$ bonds. However, the slight difference in the $\mathrm{C}-\mathrm{O}$ bond lengths of the $\mathrm{COO}^{-}$group results from the different involvement in the $\mathrm{N}-\mathrm{H} \cdots \mathrm{O}$ and $\mathrm{O}-\mathrm{H} \cdots \mathrm{O}$ hydrogen bonds. The $\mathrm{C}=\mathrm{O}$ bond length in the acetyl group shows a typical value $(1.224(2) \AA)$ observed for the carbonyl groups [36]. The $\mathrm{X}$-ray values of $\mathrm{C}-\mathrm{O}$ bonds compare well with the values obtained by molecular orbital calculations. When the conformations in the gas-phase and in the crystal are compared, different orientations of the acetyl (plane P2: C8, O3, C9) and carboxyl (plane P3: C7, 01, O2) groups around single bonds of $\mathrm{C2}-\mathrm{C} 8$ and $\mathrm{C} 1-\mathrm{C} 7$, respectively, appear. The X-ray interplanar angles between planes P1, P2, and P3 are: P1P2 $=19.1(2)^{\circ}$, $\mathrm{P} 1 \mathrm{P} 3=76.5(2)^{\circ}$, and $\mathrm{P} 2 \mathrm{P} 3=71.5(2)^{\circ}$, while in the gas-phase conformation the respective angles are: $\mathrm{P} 1 \mathrm{P} 2=112.5^{\circ}, \mathrm{P} 1 \mathrm{P} 3=6.4^{\circ}$, and $\mathrm{P} 2 \mathrm{P} 3=110.5^{\circ}$. Thus in the gas phase conformation, the carboxylate group is almost coplanar with the benzene ring, while the carbonyl is oriented to enable interaction between one $\mathrm{H}$ methyl
Table 3

Geometric parameters of the hydrogen bonds in the structure of $\mathbf{1}$ and $\mathbf{2}$

\begin{tabular}{|c|c|c|c|c|}
\hline $\mathrm{D}-\mathrm{H} \cdots \mathrm{A}$ & $\mathrm{D}-\mathrm{H}(\AA)$ & $\mathrm{H} \cdots \mathrm{A}(\AA)$ & $\mathrm{D} \cdots \mathrm{A}(\AA)$ & $<\mathrm{DHA}\left({ }^{\circ}\right)$ \\
\hline \multicolumn{5}{|l|}{ Compound 1} \\
\hline $\mathrm{N} 15-\mathrm{H} 15 \cdots \mathrm{O} 2^{i}$ & 0.86 & 1.78 & $2.633(2)$ & 170 \\
\hline 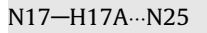 & 0.86 & 2.11 & $2.950(2)$ & 165 \\
\hline $\mathrm{N} 17-\mathrm{H} 17 \mathrm{~B} \cdots \mathrm{N} 21^{i i}$ & 0.86 & 2.32 & $3.014(2)$ & 139 \\
\hline $\mathrm{N} 18-\mathrm{H} 18 \mathrm{~A} \cdots \mathrm{O} 5^{i i i}$ & 0.86 & 2.13 & $2.911(2)$ & 151 \\
\hline $\mathrm{N} 18-\mathrm{H} 18 \mathrm{~B} \cdots \mathrm{O} 1^{i}$ & 0.86 & 1.96 & $2.819(2)$ & 179 \\
\hline N19-H19A $\cdots \mathrm{N} 13^{i}$ & 0.86 & 2.27 & $3.089(2)$ & 160 \\
\hline $\mathrm{N} 19-\mathrm{H} 19 \mathrm{~B} \cdots \mathrm{O}^{i v}$ & 0.86 & 2.15 & $2.928(2)$ & 150 \\
\hline $\mathrm{O} 3-\mathrm{H} 3 \cdots \mathrm{O} 1^{v}$ & $0.823(5)$ & $1.81(1)$ & $2.630(2)$ & $172(2)$ \\
\hline $\mathrm{O} 4-\mathrm{H} 4 \cdots \mathrm{O} 7^{v i}$ & $0.822(5)$ & $1.96(1)$ & $2.715(2)$ & 153(2) \\
\hline $\mathrm{O} 4-\mathrm{H} 4 \cdots \mathrm{O} 3$ & $0.822(5)$ & $2.30(2)$ & $2.701(2)$ & $110(2)$ \\
\hline O5-H5 $\cdots 0^{v i i}$ & $0.822(5)$ & $2.03(1)$ & $2.828(2)$ & $165(2)$ \\
\hline $\mathrm{N} 27-\mathrm{H} 27 \mathrm{~A} \cdots \mathrm{O} 7^{\text {viii }}$ & 0.86 & 2.15 & $2.946(2)$ & 153 \\
\hline $\mathrm{N} 27-\mathrm{H} 27 \mathrm{~B} \cdots \mathrm{O}^{v}$ & 0.86 & 2.35 & $3.163(2)$ & 158 \\
\hline $\mathrm{N} 28-\mathrm{H} 28 \mathrm{~B} \cdots \mathrm{N} 21^{i i}$ & 0.86 & 2.27 & $3.103(2)$ & 163 \\
\hline N29-H29A ‥N11 & 0.86 & 2.24 & $3.082(2)$ & 166 \\
\hline $\mathrm{N} 29-\mathrm{H} 29 \mathrm{~B} \cdots \mathrm{N} 13^{i}$ & 0.86 & 2.49 & $3.097(2)$ & 128 \\
\hline 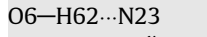 & $0.820(1)$ & $2.30(3)$ & $2.835(2)$ & $123(3)$ \\
\hline $\mathrm{O} 7-\mathrm{H} 71 \cdots \mathrm{O} 2^{v}$ & $0.820(1)$ & 1.91(1) & $2.729(2)$ & $175(2)$ \\
\hline \multicolumn{5}{|l|}{ Compound 2} \\
\hline N15-H15 ‥ 1 & 0.86 & 1.81 & $2.640(2)$ & 162 \\
\hline $\mathrm{N} 17-\mathrm{H} 17 \mathrm{~A} \cdots \mathrm{O}^{i}$ & 0.86 & 2.15 & $2.985(2)$ & 165 \\
\hline $\mathrm{N} 17-\mathrm{H} 17 \mathrm{~B} \cdots \mathrm{O} 4^{i v}$ & 0.86 & 2.10 & $2.945(2)$ & 166 \\
\hline N18-H18A ‥N25 & 0.86 & 2.11 & $2.965(2)$ & 170 \\
\hline $\mathrm{N} 18-\mathrm{H} 18 \mathrm{~B} \cdots \mathrm{O} 2^{i i i}$ & 0.86 & 2.08 & $2.800(2)$ & 141 \\
\hline $\mathrm{N} 19-\mathrm{H} 19 \mathrm{~A} \cdots \mathrm{N} 23^{i i}$ & 0.86 & 2.13 & $2.980(2)$ & 172 \\
\hline N19-H19B ‥O3 & 0.86 & 2.17 & $2.934(2)$ & 148 \\
\hline $\mathrm{N} 27-\mathrm{H} 27 \mathrm{~A} \cdots \mathrm{O} 5^{v}$ & 0.86 & 2.34 & $2.970(2)$ & 131 \\
\hline $\mathrm{N} 27-\mathrm{H} 27 \mathrm{~B} \cdots \mathrm{N} 11^{v i}$ & 0.86 & 2.14 & $2.999(2)$ & 175 \\
\hline $\mathrm{N} 28-\mathrm{H} 28 \mathrm{~A} \cdots \mathrm{O} 2^{i i i}$ & 0.86 & 2.37 & $3.219(2)$ & 172 \\
\hline $\mathrm{N} 29-\mathrm{H} 29 \mathrm{~A} \cdots \mathrm{O} 4^{i v}$ & 0.86 & 2.30 & $2.970(2)$ & 135 \\
\hline $\mathrm{N} 29-\mathrm{H} 29 \mathrm{~B} \cdots \mathrm{N} 13$ & 0.86 & 2.12 & $2.979(2)$ & 175 \\
\hline $\mathrm{O} 4-\mathrm{H} 41 \cdots \mathrm{N} 21$ & $0.84(3)$ & $2.07(3)$ & $2.906(2)$ & $176(2)$ \\
\hline $\mathrm{O} 4-\mathrm{H} 42 \cdots \mathrm{O} 1^{v i i}$ & $0.89(2)$ & $1.94(3)$ & $2.792(2)$ & $159(2)$ \\
\hline $\mathrm{O} 5-\mathrm{H} 51 \cdots \mathrm{O} 2^{i i i}$ & $0.91(3)$ & $1.83(3)$ & $2.735(2)$ & $170(2)$ \\
\hline
\end{tabular}

Codes for symmetry operations ${ }^{(i)} x, 3 / 2-y,-1 / 2+z$; ${ }^{(i i)} 1 / 2-x, y, 1 / 2+z ;{ }^{(i i i)} 1-x, 1-y$, $2-z$; ${ }^{(i v)} 1-x, 1-y, 1-z ;{ }^{(v)} x, 1 / 2-y,-1 / 2+z ;{ }^{(v i)} 1-x,-y, 1-z ;{ }^{(v i i)} 1 / 2+x,-y, 3 / 2-z$; (viii) $1 / 2-x, 1 / 2-y, z$.

Codes for symmetry operations: (i) $1-x, 1-y,-z$; ${ }^{(i i)} 1+x, y, z$; ${ }^{(i i i)} 1-x, y, 1 / 2-z$; (iv) $1 / 2-x, 3 / 2-y,-z ;{ }^{(v)}-x, 1-y,-z ;{ }^{(v i)} x-1, y, z ;{ }^{(v i i)} x-1 / 2,1 / 2+y, z$.

hydrogen and one carboxyl oxygen. In the crystal, the carboxylate group adopts rather an nearly orthogonal conformation in relation to the benzene ring, while the carbonyl double bond of acetyl group is almost eclipsed to the $\mathrm{C}_{\text {ring }}-\mathrm{COO}$ single bond. Despite this unusual internal conformation in the crystal, the oxygen atoms are involved in up to six hydrogen bonds toward melamine dimers and water molecules, which probably compensates the carbonyl-carboxyl steric and repulsion interactions.

The crystal packing of compounds 1 and 2 show rich set of the $\mathrm{N}-\mathrm{H} \cdots \mathrm{N}, \mathrm{N}-\mathrm{H} \cdots \mathrm{O}$ and $\mathrm{O}-\mathrm{H} \cdots \mathrm{O}$ hydrogen-bonding systems (Table 3 ) and $\pi-\pi$ interactions between the aromatic rings. The best way to realize such complex 3D crystal architectures is to analyse the substructures generated by basic synthons, as shown in Scheme 2. The interactions between these basic units lead to formation of stacks, chains, layers, tapes and channel patterns, developing interesting supramolecular 3D architectures.

The synthon $\mathrm{MH}^{+} \mathrm{M}$ (Scheme $2 \mathrm{a}$ ) is observed in the crystal structure of 1 as shown in Fig. 1a. They form a cationic layer nearly parallel to the crystallographic plane of (100) at $x=\ldots 1 / 4,3 / 4 \cdots$ (Fig. 2a). The protonated and non-protonated melamine units are interconnected by two almost linear $\mathrm{N}-\mathrm{H} \cdots \mathrm{N}$ hydrogen bonds, N17-H17A $\cdots \mathrm{N} 25$ and N29-H29A $\cdots$ N11 (Fig. 1a). An offset $\pi-\pi$ interaction between two $\mathrm{MH}^{+} \mathrm{M}$ dimers related to each other by a twofold axis along the $c$-axis is observed (Fig. 2b); the mean interplanar distance of $3.45(2) \AA$ indicates strong $\pi-\pi$ interaction [38]. The $c$-glide plane perpendicular to the $a$-axis provides that mutually orthogonal stacks interact with each other via hydrogen bonds through 
aza-nitrogen atoms, N13 and N21, which act as proton-acceptors from the amine nitrogen atoms of adjacent neighbouring stacks. In this way, several $\mathrm{N}-\mathrm{H} \cdots \mathrm{N}$ bonds are summed up to the dimeric $\pi-\pi$ interaction, once involving two amine nitrogen as donors $\mathrm{H}$ of $\mathrm{MH}^{+}$and $\mathrm{M}$ units toward a single aza nitrogen acceptor on $\mathrm{M}, \mathrm{v.z}$.,

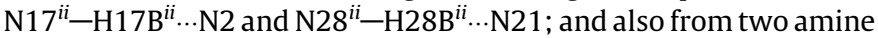
nitrogen $\mathrm{H}$-donors of $\mathrm{MH}^{+}$and $\mathrm{M}$ units toward a single aza nitrogen acceptor on $\mathrm{MH}^{+}$, v.z., N19-H19A $\cdots \mathrm{N} 13^{i}$ and N29-H29B $\cdots \mathrm{N} 13^{i}$. The $\cdots \mathrm{MH}^{+} \mathrm{M} \cdots \mathrm{MH}^{+} \mathrm{M} \cdots$ cluster of mutually orthogonal stacking dimers forming a polymeric substructure along the c-axis (Fig. 2b). Moreover, the protonated side of dimer $\mathrm{MH}^{+} \mathrm{M}$, i.e., the ring nitrogen atom $\mathrm{N} 15$ and its amine nitrogen atoms (N18) in $\mathrm{MH}^{+}$, interacts with the $\mathrm{THB}^{-}$anion while the other side interacts with water molecule (O6). The stacking unit of two parallel $\mathrm{THB}^{-}$anions, related by the

a

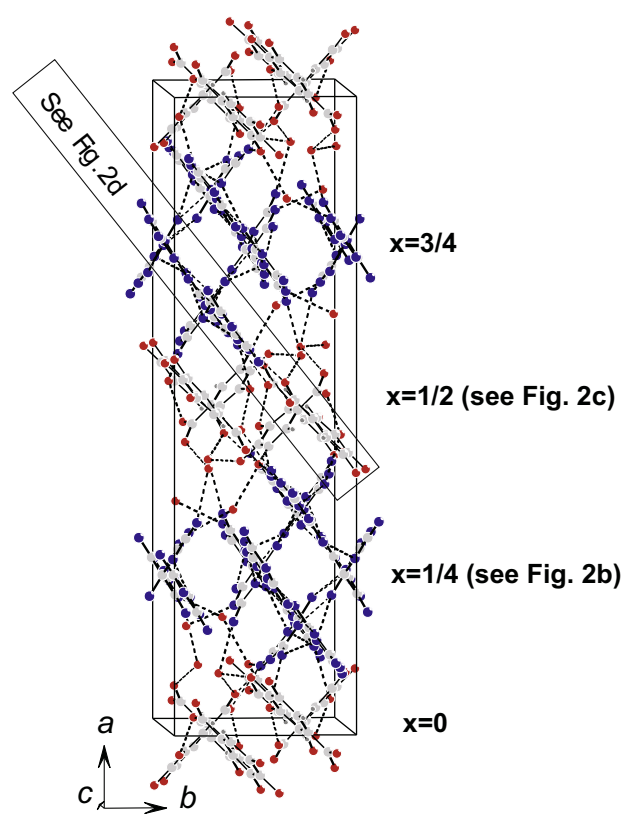

b

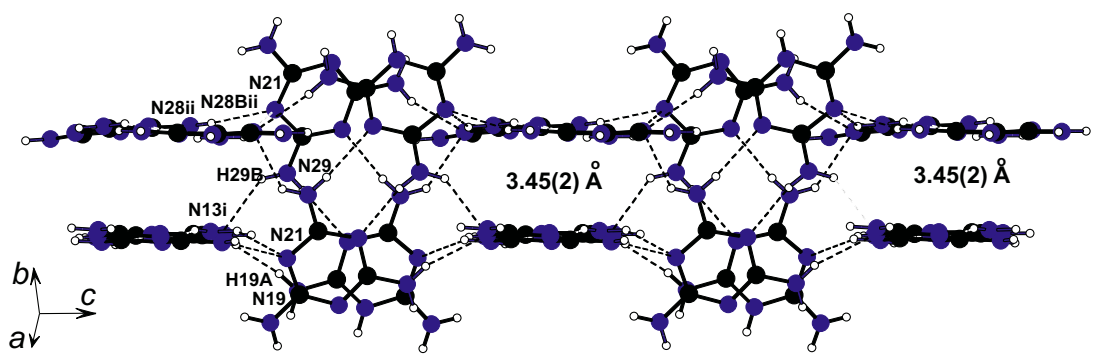

C

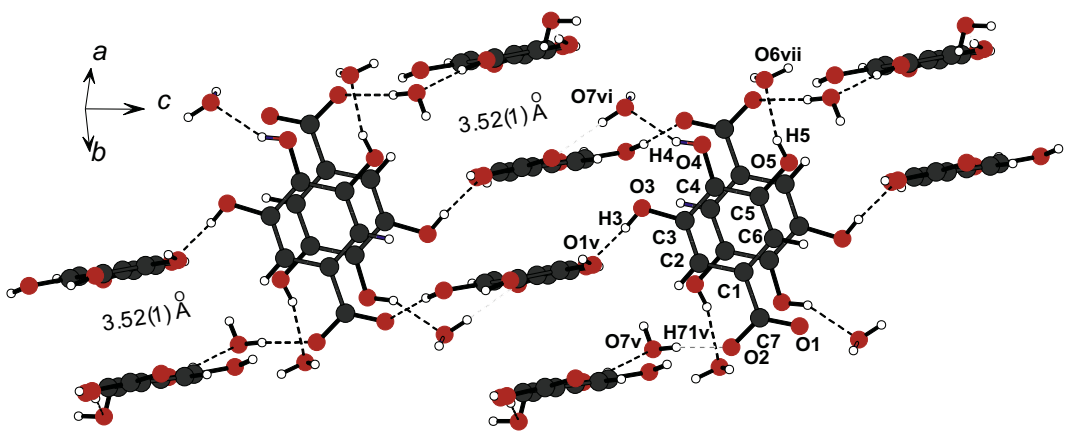

d

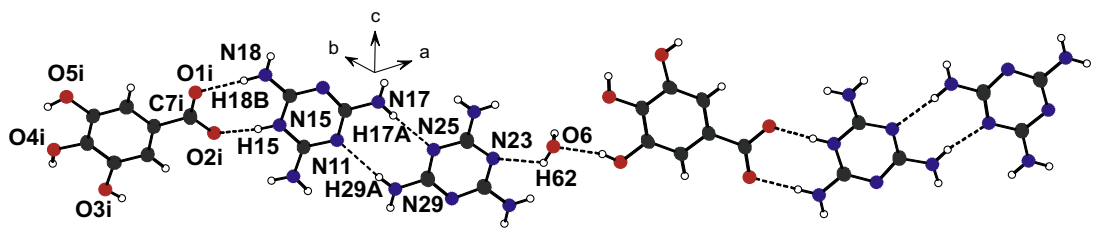

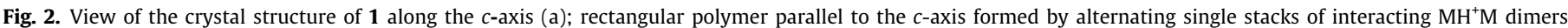

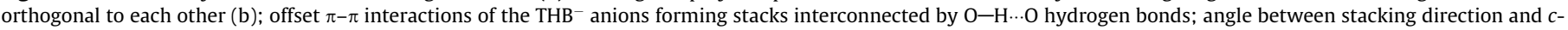
axis is $\sim 90^{\circ}$ (c) and hydrogen bonded $\mathrm{THB}^{-}$and $\mathrm{MH}^{+} \mathrm{M}$ units into $1 \mathrm{D}$ polymer via water molecules (d). Symmetry code see Table 3 . 
inversion symmetry and with an estimated interplanar distance of $\sim 3.52(1) \AA$, characterizes a strong offset of $\pi-\pi$ interaction between the benzoate anions (Fig. 2c). There are two stacking directions orthogonal to $c$-axis. Furthermore, single $\mathrm{THB}^{-}$stacks and water O7 form an anionic layer parallel to (100) crystallographic plane at $x=\cdots 0,1 / 2,1 \cdots$. Within these layers, THB $^{-}$anions of distinct stacks are linked strictly via $\mathrm{O}-\mathrm{H} \cdots \mathrm{O}$ hydrogen bonds: once directly from hydroxyl to carboxylate oxygen atoms onto $\mathrm{O} 3-\mathrm{H} 3 \cdots \mathrm{O} 1^{v}$, and secondly by means of water $\mathrm{O7}$, which bridges the anions as acceptor from the hydroxyl proton in $\mathrm{O} 4-\mathrm{H} 4 \cdots \mathrm{O} 7^{\text {vii }}$ and as donor to the carboxylate oxygen in $07-\mathrm{H} 71 \cdots 2^{v}$. Additionally, the water 06 molecule is bridging $\mathrm{THB}^{-} \mathrm{MH}^{+}$and $\mathrm{MH}^{+} \mathrm{M}$ units via $\mathrm{O}-\mathrm{H} \cdots \mathrm{O}$ bonds, being proton acceptor of hydroxyl oxygen in $05-\mathrm{H} 5 \cdots \mathrm{O} 6$, and proton donor to the aromatic nitrogen N23 of M. An interesting feature of this $3 \mathrm{D}$ arrangement is the continuous $\ldots \mathrm{THB}^{-} \mathrm{MH}^{+} \mathrm{M} \cdots \mathrm{O} 6 \ldots$ $\mathrm{THB}^{-} \mathrm{MH}^{+} \mathrm{M} \cdots \mathrm{O}$.… polymeric chains (Fig. $2 \mathrm{~d}$ ), which runs approximately along the $[1,3,0]$ directions throughout the two substructures described above.

The observed synthon $\mathrm{MH}^{+} \mathrm{M}$ in the crystal structure of 2 is shown in Fig. 1b. Each protonated and non-protonated melamine

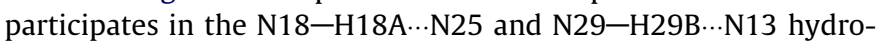
gen bonds to form the planar dimer $\mathrm{MH}^{+} \mathrm{M}$. An infinite chain $\cdots \mathrm{MH}^{+} \mathrm{M} \cdots \mathrm{MH}^{+} \mathrm{M} \cdots$ is generated by translation symmetry along the $a$-axis, enabling two additional N19-H19A $\cdots \mathrm{N} 23^{i i}$ and $\mathrm{N} 27^{i i}-\mathrm{H} 27^{i i} \ldots \mathrm{N} 15$ hydrogen bonds between two adjacent dimers, to form a tape-like 1D polymer (Fig. 3a). Dimeric pairs of neighbouring polymeric tapes, related by inversion center, are parallel to each other and separated by an interplanar distance of $\sim 3.55(1) \AA$ (between the triazine rings), characterising strong offset $\pi-\pi$ interactions. Distinct non-interacting pairs of melaminemelaminium tapes, related to each other by the $c$-glide planes, fulfil the limited region close to $y=\cdots 0,1 / 2,1 \cdots$ crystallographic planes
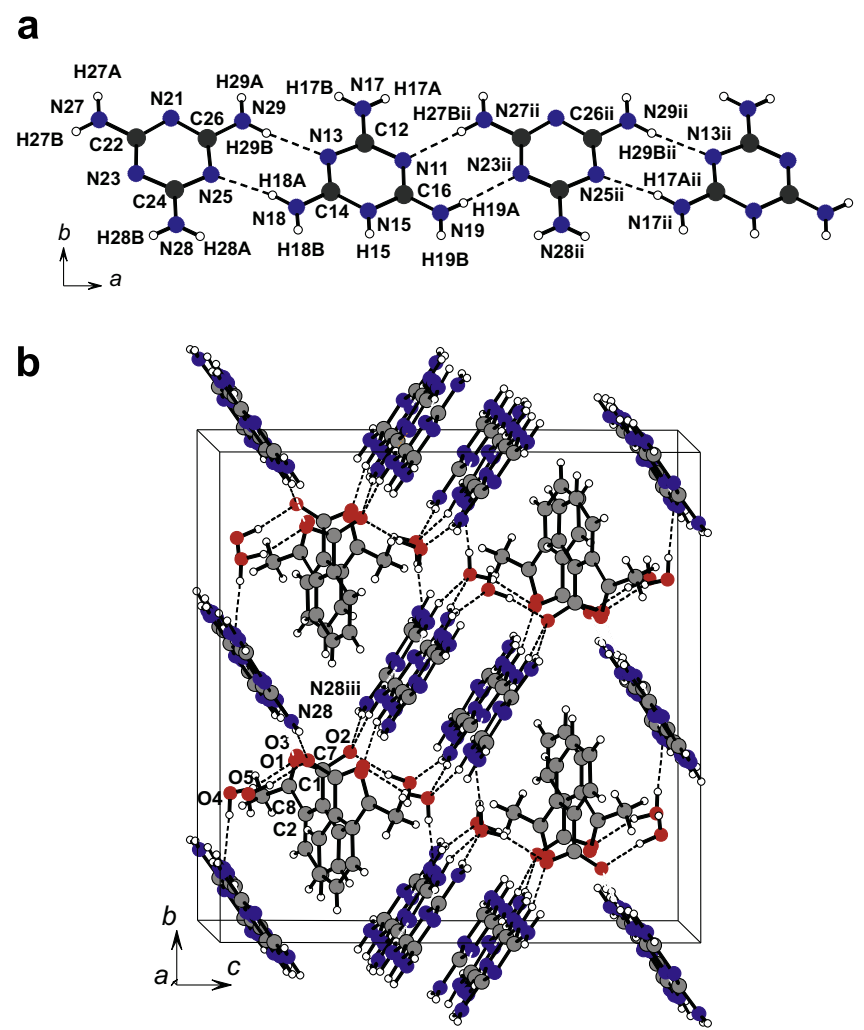

Fig. 3. View of the crystal structure of $\mathbf{2}$ showing polymeric $\mathrm{MH}^{+} \mathrm{M}$ chain running along the $a$-axis (a) and the alternating positive and negative charged layers parallel to (010) plane (b). Symmetry code see Table 3.

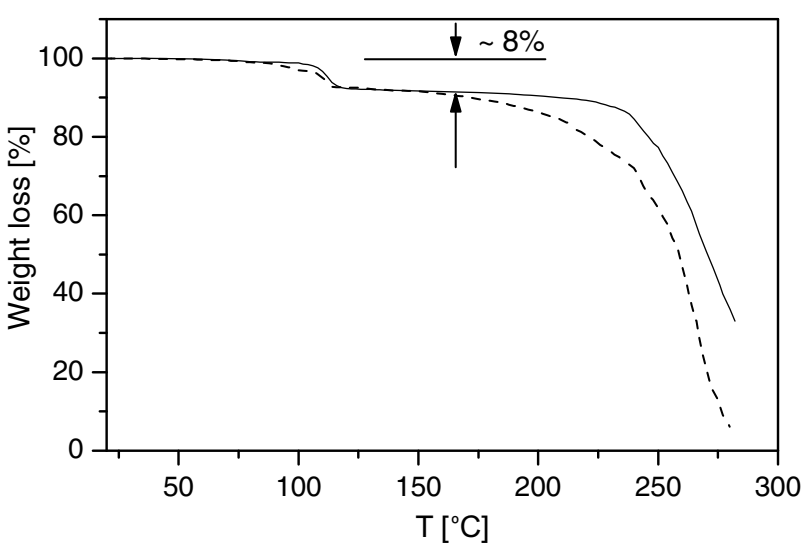

Fig. 4. Thermogravimetrig diagram of $\mathbf{1}$ (solid line) and $\mathbf{2}$ (dashed line).

perpendicular to $b$-axis, defining positive 2D layers (Fig. 3b). Furthermore, these layers interact directly with the $\mathrm{AB}^{-}$anions within the intermediate layers at $y=\ldots 1 / 4,3 / 4 \cdots$ by means of $\mathrm{N}-\mathrm{H} \cdots \mathrm{O}$ hydrogen bonds, or via bridging water molecules. No noticeable intermolecular interaction between the $\mathrm{AB}^{-}$anions takes place within an anionic layer in which the angle between two adjacent bezene rings is $13.6(1)^{\circ}$. However, the active lone electron pairs on carbonyl and carboxylate oxygen atoms (Scheme 2c) are envolved in $\mathrm{N}-\mathrm{H} \cdots \mathrm{O}$ hydrogen bonds to neighbouring $\mathrm{MH}^{+} \mathrm{M}$ dimers, $\mathrm{N} 15-\mathrm{H} 15 \cdots \mathrm{O} 1, \quad \mathrm{~N} 19-\mathrm{H} 19 \mathrm{~B} \cdots \mathrm{O} 3, \quad \mathrm{~N} 28-\mathrm{H} 28 \mathrm{~A} \cdots \mathrm{O} 2^{i i i}$, and $\mathrm{N} 17-\mathrm{H} 17 \mathrm{~B} \cdots \mathrm{O} 2^{i i i}$. Additionally, each water molecule acts as $\mathrm{H}-$ donor to $\mathrm{O}$ atoms of $\mathrm{COO}^{-}$group, to form $\mathrm{O}-\mathrm{H} \cdots \mathrm{O}$ bonds, $\mathrm{O} 4-\mathrm{H} 42 \cdots \mathrm{O} 1^{v i i}$ and $\mathrm{O} 5-\mathrm{H} 51 \cdots \mathrm{O} 2^{i i i}$. Furthermore, the water $\mathrm{O} 4$ and 05 molecules act twicely as acceptor in two hydrogen bonds: $\mathrm{N} 29-\mathrm{H} 29 \mathrm{~A} \cdots \mathrm{O} 4^{i i}$ and $\mathrm{N} 17-\mathrm{H} 17 \mathrm{~B} \cdots \mathrm{O} 4^{i i}$ hydrogen bonds within one dimer and N27-H27A $\cdots 05^{v}$ and $\mathrm{N} 1-\mathrm{H} 17 \mathrm{~A} \cdots 05^{i}$ hydrogen bonds of distinct dimers, which can be seen as bridges between low-dimensional arrangements in a 3D network.

Although the water molecules are hydrogen bonded to the organic framework in both crystals, the TGA study (Fig. 4) shows a weight loss of about $8 \%$ in the temperature range of $90-110^{\circ} \mathrm{C}$, which is close to the theoretical value of $7.85 \%$ and $7.96 \%$ in 1 and 2, respectively, for the loss of water molecules. Both TGA curves imply that the host framework remains stable below $200{ }^{\circ} \mathrm{C}$, upon removing the water molecules. Further heating leads to sublimation of the compounds, what illustrates the quick weight loss of the samples.

\section{Conclusions}

Upon self-recognition two new melamine-melaminium aromatic carboxylate dihydrate co-crystals are formed. X-ray single crystal results have been compared with those obtained by theoretical calculations. The quantum-mechanical predicted geometries resulted in a conformation of the $\mathrm{AB}^{-}$anion quite different from that observed in the crystal. These co-crystals are the examples where protonated and non-protonated melamine molecules coexist in the crystalline state. They have important structural properties: besides the strong tendency to dimerize, the protonation site enables interactions with the neighbouring anions, at the same time preserving strong $\pi-\pi$ interactions between the triazine rings.

\section{Supplementary material}

The X-ray crystallographic data for the structures reported in this paper have been deposited at the CCDC as supplementary data, 
CCDC Nos. 667507 and 667506 for (1) and (2), respectively. Copies of the data can be obtained on application to CCDC, 12 Union Road, Cambridge CB2 1EZ, UK. E-mail: deposit@ccdc.cam.ac.uk.

\section{Acknowledgment}

This work was financially supported by the Ministry of Science and Information Society Technologies (Project No. 3 T09A 121 28).

\section{References}

[1] J.D. Wuest, Chem. Commun. (2005) 5830.

[2] G.R. Desiraju, J. Mol. Struct. 374 (1996) 191

[3] G.R. Desiraju, J. Mol. Struct. 656 (2003) 5.

[4] J.C. MacDonald, G.M. Whitesides, Chem. Rev. 94 (1994) 2382.

[5] G.M. Whitesides, E.E. Siemanek, J.P. Mathias, C.T. Seto, D.N. Chin, M. Mammen, D.M. Gordon, Acc. Chem. Res. 28 (1995) 37.

[6] G.R. Desiraju, Angew. Chem. Int. Ed. Engl. 34 (1995) 2311.

[7] T. Steiner, Angew. Chem. Int. Ed. Engl. 41 (2002) 48.

[8] J.A. Zerkowski, C.T. Seto, D.A. Wierda, G.M. Whitesides, J. Am. Chem. Soc. 112 (1990) 9025.

[9] G.R. Desiraju (Ed.), Perespectives in Supramolecular Chemistry: The Crystal as a Supramolecular Entity, vol. 2, Wiley, Chichester, 1996.

[10] M.J. Krische, J.M. Lehn, Struct. Bonding 96 (2000) 3.

[11] J.A. Zerkowski, G.M. Whitesides, J. Am. Chem. Soc. 116 (1994) 4298.

[12] T.G.N. Row, Coord. Chem. Rev. 183 (1999) 81.

[13] J.A. Zerkowski, J.C. MacDonald, C.T. Seto, D.A. Wierda, G.M. Whitesides, J. Am. Chem. Soc. 116 (1994) 2382.

[14] J.A. Zerkowski, J.C. MacDonald, G.M. Whitesides, Chem. Mater. 6 (1994) 1250

[15] G.R. Desiraju, Crystal Engineering. The Design of Organic Solids, Elsevier Science Publisher B.V., Amsterdam, 1989.

[16] G.R. Desiraju, Acc. Chem. Res. 29 (1996) 441

[17] M. Muthuraman, Y. Le-Fur, M. Bagien-Beucher, R. Masse, J.F. Nicoud, S. George, A. Nangia, G.R. Desiraju, J. Solid State Chem. 152 (2000) 211.

[18] G.R. Desiraju, T. Steiner, The Weak Hydrogen Bonds in Structural Chemistry and Biology, Oxford University Press, Oxford, 1999.

[19] M. Marchewka, J. Janczak, S. Debrus, J. Baran, H. Ratajczak, Solid State Sci. 5 (2003) 643.

[20] G.J. Perpétuo, J. Janczak, Acta Crystallogr. C62 (2006) 0372.

[21] J. Janczak, G.J. Perpétuo, Acta Crystallogr. C58 (2006) 0455.

[22] A. Ranganathan, V.R. Pedireddi, C.N.R. Rao, J. Am. Chem. Soc. 121 (1999) 1752.

[23] (a) J. Janczak, G.J. Perpétuo, Acta Crystallogr. C57 (2001) 123;

(b) J. Janczak, G.J. Perpétuo, Acta Crystallogr. C57 (2001) 873;

(c) J. Janczak, G.J. Perpétuo, Acta Crystallogr. C57 (2001) 1120;

(d) J. Janczak, G.J. Perpétuo, Acta Crystallogr. C57 (2001) 1431; (e) G.J. Perpétuo, J. Janczak, Acta Crystallogr. C58 (2002) o112;

(f) J. Janczak, G.J. Perpétuo, Acta Crystallogr. C58 (2002) 0339;

(g) J. Janczak, G.J. Perpétuo, Acta Crystallogr. C59 (2003) o349

(h) G.J. Perpétuo, J. Janczak, Polish J. Chem. 77 (2003) 1323;

(i) J. Janczak, G.J. Perpétuo, Acta Crystallogr. C60 (2004) o211;

(j) G.J. Perpétuo, M.A. Ribero, J. Janczak, Acta Crystallogr. E61 (2005) o287.

[24] (a) R. Tanbug, K. Kirschbaum, A.A. Pinkerton, J. Chem. Crystallogr. 29 (1999) 45 ;

(b) A. Roy, A. Choudhury, C.N.R. Rao, J. Mol. Struct. 613 (2002) 61;

(c) L.E. Gordon, W.T.A. Harrison, Acta Crystallogr. E59 (2003) o195;

(d) M.K. Marchewka, J. Baran, A. Pietraszko, A. Haznar, S. Debrus, H. Ratajczak, Solid State Sci. 5 (2003) 509;

(e) J. Zhang, Y. Kang, Y.H. Wen, Z.J. Li, Y.Y. Qin, Y. Yao, Acta Crystallogr. E60 (2004) 0462;

(f) C.S. Choi, R. Venkatraman, E.H. Kim, H.S. Hwang, S.K. Kang, Acta Crystallogr. C60 (2004) o295;

(g) X.M. Li, L.P. Lu, S.S. Feng, H.M. Znang, S.D. Qin, M.L. Zhu, Acta Crystallogr. E61 (2005) 0811;

(h) X.L. Zhang, X.M. Chen, Cryst. Growth Des. 5 (2005) 617;

(i) X.L. Zhang, X.M. Chen, S.W. Ng, Acta Crystallogr. E61 (2005) o156;

(j) K.U. Lakshmi, S. Thamotharan, K. Ramamurthi, B. Varghese, Acta Crystallogr. E62 (2006) 0455.

[25] F.A. Allen, Acta Crystallogr. B58 (2002) 380.

[26] X.L. Zhang, B.H. Ye, X.M. Chen, Cryst. Growth Des. 5 (2005) 1609.

[27] J. Janczak, G.J. Perpétuo, Acta Crystallogr. C64 (2008) o91.

[28] KUMA DIFFRACTION, KUMA KM-4 CCD Software, Ver. 171.3, Wrocław, Poland, 2004.

[29] G.M. Sheldrick, Acta Crystallogr. A32 (1990) 751

[30] G.M. Sheldrick, SHELXS97, SHELXL97, Programs for Crystal Structures Solution and Refinement, University of Göttingen, Göttingen, Germany, 1997.

[31] J.M. Frisch, G.W. Trucks, H.B. Schlegel, P.M.W. Gill, B.G. Johnson, M.A. Robb, J. Cheeseman, T. Keith, G.A. Petersson, J.A. Montgomery, K. Raghavachari, M.A. Al-Laham, V.G. Zakrzewski, J.V. Ortiz, J.B. Foresman, J. Cislowski, B.B. Stefanov, A. Nanayakkara, M. Challacombe, C.Y. Peng, P.Y. Ayala, W. Chen, W.M. Wong, J.L. Andres, E.S. Replogle, R. Gomperts, R.L. Martin, D.J. Fox, J.S. Binkley, D.J. Defrees, J. Baker, B.B. Stewart, M. Head-Gordon, C. Gonzales, J.A. Pople, Gaussian98 Revision A.3, Gaussian, Inc., Pittsburgh PA, 1998.

[32] A.D. Becke, J. Chem. Phys. 104 (1996) 1040-1046.

[33] C. Lee, W. Yang, R.G. Parr, Phys. Rev. B37 (1988) 785.

[34] N. Stanley, V. Sethraman, P.T. Muthiah, P. Luger, M. Weber, Cryst. Growth Des. 2 (2002) 631.

[35] S.B. Raj, N. Stanley, P.T. Muthiah, G. Bocelli, R. Ollá, A. Cantoni, Cryst. Growth Des. 3 (2003) 567

[36] F.H. Allen, O. Kennard, D.G. Watson, L. Brammer, A.G. Orpen, J. Chem. Soc Perkin Trans. 2 (1987) S1-S19.

[37] R.J. Gillespie, Chem. Soc. Rev. 21 (1992) 59.

[38] L. Pauling, In The Chemical Bond: A Brief Introduction to Modern Structural Chemistry, Cornell University Press, Ithaca, New York, 1967. Chapter 3. 